\title{
Soil Persistence of Chlorimuron-Ethyl and Metsulfuron-Methyl and Phytotoxicity to CoRn Seeded as a SuCCEeding CROP ${ }^{1}$
}

\author{
Persistência de Chlorimuron-Ethyl e Metsulfuron-Methyl no Solo e Fitotoxicidade à Cultura do \\ Milho Semeada em Sucessão
}

CARVALHO, S.J.P. ${ }^{2}$, SOARES, D.J. ${ }^{3}$, LOPEZ-OVEJERO, R.F. ${ }^{3}$, and CHRISTOFFOLETI, P.J. ${ }^{4}$

\begin{abstract}
Two experiments were carried out to evaluate soil persistence of chlorimuronethyl and metsulfuron-methyl and phytotoxicity to corn seeded as a succeeding crop. One experiment was conducted with chlorimuron-ethyl applied at $20 \mathrm{~g} \mathrm{ha}^{-1}$, and one with metsulfuron-methyl applied at $3.96 \mathrm{~g} \mathrm{ha}^{-1}$. Treatments were arranged in a factorial design with two types of soil (sandy and clay), three irrigation regimes (daily, weekly and no irrigation) and four application timings (90, 60 and 30 days before corn seeding, as well as untreated plots). Soil persistence of the herbicides was influenced by water availability, molecule water solubility (leaching potential) and application timings prior to corn seeding. In sandy soil, with adequate water availability, leaching probably had the greatest influence, reducing the persistence of the products, and consequently allowing less time between product application and corn seeding. In clay soil, microbial degradation was probably more important, because it was assumed that the lesser time available for microorganism activity, the lesser the damage was observed for corn, as long as the crop had enough water availability. Metsulfuronmethyl was the least phytotoxic herbicide, possibly as a result of the properties of its molecule and its higher leaching potential.
\end{abstract}

Keywords: carryover, leaching, microbial degradation, dynamics.

\begin{abstract}
RESUMO - Dois experimentos foram desenvolvidos com o objetivo de avaliar a persistência de chlorimuron-ethyl e metsulfuron-methyl no solo e a fitotoxicidade à cultura do milho cultivado em sucessão: um com o herbicida chlorimuron-ethyl aplicado a $20 \mathrm{~g} \mathrm{ha}^{-1}$; e outro com metsulfuronmethyl aplicado a 3,96 $\mathrm{g} \mathrm{ha}^{-1}$. Os tratamentos foram organizados em esquema fatorial com dois tipos de solo (argiloso e arenoso), três regimes de irrigação (diário, semanal e ausente) e quatro épocas de aplicação do produto (90, 60 e 30 dias anteriores à semeadura do milho, além de testemunha sem aplicação). A persistência dos herbicidas foi influenciada pela disponibilidade hidrica, pela solubilidade da molécula em água (potencial de lixiviação) e pelo período de tempo anterior à semeadura do milho. Em solo arenoso, com adequada disponibilidade hídrica, provavelmente a lixiviação teve maior influência, reduzindo a persistência dos produtos e, consequentemente, permitindo menor tempo entre a aplicação deles e a semeadura do milho. Em solo argiloso, possivelmente a degradação microbiana teve maior importância, presumindo-se assim que, quanto maior o periodo hábil para a atividade microbiana, menor a fitotoxicidade observada no milho, desde que em ambiente com adequada disponibilidade hidrica. O herbicida metsulfuron-methyl foi menos fitotóxico às plantas de milho, possivelmente devido às características da molécula e seu maior potencial de lixiviação.
\end{abstract}

Palavras-chave: atividade residual, lixiviação, degradação microbiana, dinâmica.

1 Recebido para publicação em 2.2.2015 e aprovado em 2.2.2015.

2 Instituto Federal do Sul de Minas Gerais, Campus Machado, Machado-MG. Brasil, <sjpcarvalho@yahoo.com.br>; ${ }^{3}$ Monsanto do Brasil, São Paulo-SP. Brasil; ${ }^{4}$ Universidade de São Paulo, Escola Superior de Agricultura “Luiz de Queiroz”, Piracicaba-SP, Brasil. 


\section{INTRODUCTION}

Currently, a major concern about weed management in the agricultural scenario in Brazil and abroad is the constant selection of new biotypes of glyphosate-resistant weeds. In Brazil, up to date, there are six weed species whose populations are resistant to this herbicide: Lolium multiflorum, Conyza bonariensis, C. canadensis, C. sumatrensis, Digitaria insularis and, more recently, Chloris elata (Heap, 2014).

When a resistant weed population is selected in a given area, changes are needed in the management practices used for such population (Moreira et al., 2010). According to Peterson (1999), the most common change adopted by farmers is the inclusion of alternative herbicides in the production system, either applied alone or tank-mixed with herbicides to which weed resistance had been detected. For management of glyphosateresistant horseweed (Conyza spp.) in soybean (Glycine max) crops, other molecules are often used, especially chlorimuron-ethyl (Carvalho \& Cavazzana, 2000; Santos et al., 2014) and metsulfuron-methyl (Moreira et al., 2010; Paula et al., 2011).

However, seeding corn as a succeeding crop (also known as second-corn crop) after soybean harvest is a common practice in Brazil (Artuzi \& Contiero, 2006). Currently, early and very early soybean cultivars are often used, together with early harvesting techniques. As a result, the time interval between soybean harvest and seeding of succeeding crops is reduced, increasing the risk of any adverse effects caused by the residual activity of herbicides applied in soybean over succeeding agricultural crops seeded in the same area (Dan et al., 2012).

Moreover, in fallow fields or in off-season, one option is to control resistant weeds prior to planting by applying glyphosate associated with other molecules (Valente \& Cavazzana, 2000; Moreira et al., 2010), whose residual effect may also affect the corn to be seeded in the area. In the environment, herbicides are dissipated through different processes and with different speeds, influenced by the physicochemical properties of the molecule, by soil properties, climate conditions or by the interaction of these factors (Christoffoleti et al., 2009).

Many processes involved in the behavior of herbicides in the environment are still unknown; however, understanding the soilplant-herbicide interaction is crucial for using the proper herbicide for each soil type, with greater efficacy and less environmental contamination (Oliveira Júnior et al., 2006). According to Ogg Júnior \& Dowler (1988), the amount of rain or irrigation water applied to a given area after herbicide spraying may also interfere on the distribution, movement, persistence and effectiveness of the product, as well as crop tolerance to the herbicide.

Thus, this study was carried out to evaluate soil persistence of chlorimuron-ethyl and metsulfuron-methyl and phytotoxicity to corn grown as a succeeding crop, while considering two soil types, different irrigation systems and intervals between herbicide applications and corn sowing.

\section{MATERIALS AND METHODS}

Two experiments were carried out in Santa Cruz das Palmeiras-SP (21 ${ }^{\circ} 49^{\prime} 07^{\prime \prime} \mathrm{S}$, 47 16' 06" $\mathrm{W}$ and $684 \mathrm{~m}$ altitude) between March and July 2010: one experiment with herbicide chlorimuron-ethyl and one with metsulfuron-methyl. Corn was seeded as a succeeding crop, using the hybrid DKB390YGRR as a bioindicator of phytotoxicity and soil persistence of the herbicides.

The treatments were organized in a triple factorial design ( $2 \times 3 \times 4)$ : two soil types (clay and sandy; Tables 1 and 2); three irrigation regimes: daily irrigation $(5 \mathrm{~mm})$, intermittent with only one weekly irrigation $(5 \mathrm{~mm})$, and no irrigation; and four product application timings: 90, 60 and 30 days before seeding (DBS) of corn and a control with no application. After corn was seeded, all plots were irrigated daily until the end of the experiments.

The plots consisted of $8.5 \mathrm{~L}$ plastic pots, filled with clay soil or sandy soil, previously sieved and crumbled, depending on the type of treatment. Each experiment (herbicide) used a randomized block design with four replications, resulting in 96 plots. Applications were made in a staggered manner, so that 
Table 1 - Physicochemical properties of the clay soil used in the experiments. Santa Cruz das Palmeiras - SP, 2010

\begin{tabular}{|c|c|c|c|c|c|c|c|c|}
\hline \multicolumn{9}{|c|}{ Grain size analysis } \\
\hline \multicolumn{3}{|c|}{ Sand } & \multirow{2}{*}{ Silt } & \multirow{2}{*}{ Clay } & \multicolumn{3}{|c|}{ Density } & \multirow{2}{*}{ Textural class } \\
\hline Coarse & Fine & Total & & & Real & & & \\
\hline \multicolumn{5}{|c|}{$(\%)$} & \multicolumn{3}{|c|}{$\left(\mathrm{g} \mathrm{cm}^{-3}\right)$} & \multirow{2}{*}{ Clay } \\
\hline 8.2 & 16.3 & 24.5 & 16.5 & 59.0 & 2.7 & & & \\
\hline \multicolumn{9}{|c|}{ Chemical analysis $^{\underline{1} /}$} \\
\hline \multicolumn{4}{|c|}{$\mathrm{pH}$} & & $\mathrm{P}_{\text {resin }}$ & $\mathrm{OM}$ & $\mathrm{C}$ & $\mathrm{CEC}$ \\
\hline$\left(\mathrm{CaCl}_{2}\right)$ & & $\left(\mathrm{H}_{2} \mathrm{O}\right)$ & (SMP) & & $\left(\mathrm{mg} \mathrm{dm}^{-3}\right)$ & \multicolumn{2}{|c|}{$\left(\mathrm{g} \mathrm{dm}^{-3}\right)$} & $\left(\mathrm{mmol}_{\mathrm{c}} \mathrm{dm}^{-3}\right)$ \\
\hline 5.7 & \multicolumn{2}{|r|}{6.4} & 6.75 & \multicolumn{2}{|r|}{76} & 28 & 16 & 99 \\
\hline $\mathrm{K}$ & \multicolumn{2}{|r|}{$\mathrm{Ca}$} & $\mathrm{Mg}$ & \multirow{2}{*}{\multicolumn{2}{|c|}{$\mathrm{H}+\mathrm{Al}$}} & \multicolumn{2}{|c|}{ SB } & $\mathrm{V}$ \\
\hline \multicolumn{6}{|c|}{$\left(\mathrm{mmol}_{\mathrm{c}} \mathrm{dm}^{-3}\right)$} & & & $(\%)$ \\
\hline 7.0 & \multicolumn{2}{|r|}{55} & 18 & \multicolumn{2}{|r|}{19} & \multicolumn{2}{|c|}{80} & 80.81 \\
\hline
\end{tabular}

1/ OM - organic matter; CEC - cation exchange capacity; SB - sum of bases; V - base saturation.

Table 2 - Physicochemical properties of the sandy soil used in the experiments. Santa Cruz das Palmeiras - SP, 2010

\begin{tabular}{|c|c|c|c|c|c|c|c|c|}
\hline \multicolumn{9}{|c|}{ Grain size analysis } \\
\hline \multicolumn{3}{|c|}{ Sand } & \multirow{2}{*}{ Silt } & \multirow{2}{*}{ Clay } & \multicolumn{3}{|c|}{ Density } & \multirow{2}{*}{ Textural class } \\
\hline Coarse & Fine & Total & & & Real & & & \\
\hline \multicolumn{5}{|c|}{$(\%)$} & \multicolumn{3}{|c|}{$\left(\mathrm{g} \mathrm{cm}^{-3}\right)$} & \multirow{2}{*}{ Sandy loam } \\
\hline 70.6 & 14.1 & 84.7 & 2.1 & 13.2 & 2.7 & \multicolumn{2}{|c|}{1.4} & \\
\hline \multicolumn{9}{|c|}{ Chemical analysis $^{{ }^{\prime}}$} \\
\hline \multicolumn{4}{|c|}{$\mathrm{pH}$} & & & OM & $\mathrm{C}$ & $\mathrm{CEC}$ \\
\hline$\left(\mathrm{CaCl}_{2}\right)$ & & $\left(\mathrm{H}_{2} \mathrm{O}\right)$ & (SMP) & & & \multicolumn{2}{|c|}{$\left(\mathrm{g} \mathrm{dm}^{-3}\right)$} & $\left(\mathrm{mmol}_{\mathrm{c}} \mathrm{dm}^{-3}\right)$ \\
\hline 5.5 & \multicolumn{2}{|r|}{6.3} & 6.70 & \multicolumn{2}{|c|}{34} & 24 & 14 & 61 \\
\hline $\mathrm{K}$ & \multicolumn{2}{|r|}{$\mathrm{Ca}$} & $\mathrm{Mg}$ & \multirow{2}{*}{\multicolumn{2}{|c|}{$\mathrm{H}+\mathrm{Al}$}} & \multicolumn{2}{|c|}{ SB } & $\mathrm{V}$ \\
\hline \multicolumn{6}{|c|}{$\left(\mathrm{mmol}_{\mathrm{c}} \mathrm{dm}^{-3}\right)$} & & & $(\%)$ \\
\hline 1.0 & \multicolumn{2}{|r|}{29} & 11 & \multicolumn{2}{|c|}{20} & \multicolumn{2}{|c|}{41} & 67.21 \\
\hline
\end{tabular}

1/ OM - organic matter; CEC - cation exchange capacity; SB - sum of bases; V - base saturation.

corn was seeded at the same time, with density of six seeds per pot at a depth of $0.03 \mathrm{~m}$.

The herbicide chlorimuron-ethyl was sprayed at a rate of $20 \mathrm{~g}$ a.i. ha- $\mathrm{ha}^{-1}$, and metsulfuron-methyl, at a rate of $3.96 \mathrm{~g}$ a.i. ha-1, as recommended by the manufacturer. Applications were made with the aid of a $\mathrm{CO}_{2}$ pressurized backpack sprayer coupled to TT 110.015 four-tip spray nozzles, $0.50 \mathrm{~m}$ away from the target, properly calibrated for spray volume of $120 \mathrm{~L} \mathrm{ha}^{-1}$.

Phytotoxicity to corn plants was measured at 7 and 14 days after emergence (DAE) by the
EWRC scale (1964), whose rates range between 1 and 9, where 1 represents no symptoms and 9 , plant death. At 21 DAE, dry matter weight of corn was evaluated by collecting up all shoots of the plants remaining in the plots. The material was dried in a forced air circulation oven at $60{ }^{\circ} \mathrm{C}$ for 72 hours to constant weight.

In each experiment, data underwent the F-test in the analysis of variance followed by Tukey's test, both at 5\% significance. The check plots were used to standardize the phytotoxicity evaluations, but they were excluded from the statistical analysis 
of phytotoxicity because they had not been assigned any scores. When factorial interaction was detected, it was decomposed by analyzing the participation of treatment factors, also at $5 \%$ significance.

\section{RESULTS AND DISCUSSION}

Through analysis of variance, the evaluation of soil persistence of the herbicide chlorimuron-ethyl identified the effects of irrigation (I), application timings (T) and I x T interaction for all the variables (Table 3). Additionally, interaction was identified between soil type (S) and I at 14 DAE. There was isolated effect of S on dry matter weight, as well as $\mathrm{S} \times \mathrm{T}$ interaction was observed (Table 3).

The isolated effect of soil on dry matter weight (Table 3) should be interpreted with caution, given that plants naturally had better development in clay soil, possibly because such soil type has better physicochemical properties, for example, sum of bases (SB) and base saturation (V\%) (Tables 1 and 2). The $\mathrm{S} \times \mathrm{I}$ interaction clarifies the experimental results (Table 4). Higher phytotoxicity at 14 DAE was identified for plots that were not irrigated before corn seeding. Conversely and consistently, higher dry matter weight was recorded for corn grown in clay soil, with previous daily irrigation (Table 4).

According to Rodrigues \& Almeida (2011), the herbicide chlorimuron-ethyl has $\mathrm{K}_{\text {ow }}$ of 320 at $\mathrm{pH} 5$ and 2.3 at $\mathrm{pH} 7$; this herbicide is a weak acid with pKa of 4.2. For ionizable herbicides, the residual effect and persistence in the environment are dependent on clay, organic matter and soil $\mathrm{pH}$ contents (Milanova \& Grigorov, 1996). According to Christoffoleti et al. (2009), the solubility of this molecule is considered as high and is influenced by soil $\mathrm{pH}$. In aqueous solution at $\mathrm{pH} 5.0$, solubility is $11 \mathrm{mg} \mathrm{L}^{-1}$; at pH 6.5, $450 \mathrm{mg} \mathrm{L}^{-1}$; and at $\mathrm{pH} 7.0$, $1,200 \mathrm{~g} \mathrm{~L}^{-1}$ (Krevalis et al., 2006; Rodrigues \& Almeida, 2011).

Table 3 - Analysis of variance and comparison of means ${ }^{1 /}$ for phytotoxicity (7 and 14 days after emergence (DAE)) and dry matter weight (g per plant; $21 \mathrm{DAE}$ ) of corn plants seeded in soil previously sprayed with chlorimuron-ethyl. Santa Cruz das Palmeiras - SP, 2010

\begin{tabular}{|c|c|c|c|}
\hline Cause of variation & Phytotoxicity at $7 \mathrm{DAE}$ & Phytotoxicity at $14 \mathrm{DAE}$ & Dry matter \\
\hline Soil (S) & $\mathrm{ns}$ & ns & $* *$ \\
\hline Irrigation (I) & $* *$ & $* *$ & $* *$ \\
\hline Application Timing (T) & $* *$ & $* *$ & $* *$ \\
\hline $\mathrm{S} \times \mathrm{I}$ & ns & $* *$ & $* *$ \\
\hline $\mathrm{S} \times \mathrm{T}$ & ns & ns & $* *$ \\
\hline $\mathrm{I} \times \mathrm{T}$ & $* *$ & $*$ & $*$ \\
\hline $\mathrm{S} \times \mathrm{I} \times \mathrm{T}$ & ns & ns & ns \\
\hline \multicolumn{4}{|c|}{ Soil type (S) } \\
\hline Clay & 3.5 & 3.0 & $3.36 \mathrm{a}$ \\
\hline Sandy & 3.6 & 2.9 & $2.46 \mathrm{~b}$ \\
\hline \multicolumn{4}{|c|}{ Irrigation $(\mathrm{I})$} \\
\hline Daily & $2.6 \mathrm{~b}$ & $2.1 \mathrm{~b}$ & $3.36 \mathrm{a}$ \\
\hline Intermittent & $2.9 \mathrm{~b}$ & $2.0 \mathrm{~b}$ & $3.01 \mathrm{~b}$ \\
\hline No irrigation & $5.2 \mathrm{a}$ & $4.8 \mathrm{a}$ & $2.38 \mathrm{c}$ \\
\hline \multicolumn{4}{|c|}{ Application Timing (T) } \\
\hline Control & --- & --- & $3.31 \mathrm{a}$ \\
\hline $30 \mathrm{DBS}^{2 /}$ & $4.4 \mathrm{a}$ & $3.7 \mathrm{a}$ & $2.53 \mathrm{~b}$ \\
\hline 60 DBS & $3.6 \mathrm{~b}$ & $3.0 \mathrm{~b}$ & $2.76 \mathrm{~b}$ \\
\hline $90 \mathrm{DBS}$ & $2.7 \mathrm{c}$ & $3.3 \mathrm{c}$ & $3.06 \mathrm{a}$ \\
\hline
\end{tabular}

${ }^{1 /}$ Means followed by the same letter in the columns do not differ by Tukey's test at 5\% significance; ${ }^{2 /}$ DBS - days before sowing;

$*$ F test significant at $5 \%$ probability; ** F-test significant at $1 \%$ probability; ${ }^{\text {ns }}$ Non-significant. 
Table 4 - Phytotoxicity (14 $\mathrm{DAE}^{1}$ ) and dry matter weight (21 DAE) of corn²/ plants seeded in soil previously sprayed with chlorimuron-ethyl, influenced by soil type and irrigation regime. Santa Cruz das Palmeiras - SP, 2010

\begin{tabular}{|c|c|c|c|}
\hline \multirow{2}{*}{$\begin{array}{l}\text { Soil type } \\
\text { (S) }\end{array}$} & \multicolumn{3}{|c|}{ Irrigation regime (I) } \\
\hline & Daily $\underline{3} /$ & Intermittent & No irrigation \\
\hline \multicolumn{4}{|c|}{ Phytotoxicity at $14 \mathrm{DAE}$} \\
\hline Sand & $2.5 \mathrm{aB}$ & $2.1 \mathrm{aB}$ & $4.3 \mathrm{bA}$ \\
\hline \multirow[t]{2}{*}{ Clay } & $1.7 \mathrm{bB}$ & $2.0 \mathrm{aB}$ & $5.4 \mathrm{aA}$ \\
\hline & $\mathrm{LSD}_{\text {Column }}=0.668$ & $\mathrm{LSD}_{\text {Row }}=0.803$ & $\mathrm{CV}(\%)=25.28$ \\
\hline \multicolumn{4}{|c|}{ Dry Matter Weight at 21 DAE } \\
\hline Sand & $2.54 \mathrm{aAB}$ & $2.62 \mathrm{bA}$ & $2.23 \mathrm{bB}$ \\
\hline Clay & $4.17 \mathrm{bA}$ & $3.39 \mathrm{aB}$ & $2.53 \mathrm{aC}$ \\
\hline & $\mathrm{LSD}_{\text {Column }}=0.261$ & $\mathrm{LSD}_{\mathrm{Row}}=0.314$ & $\mathrm{CV}(\%)=12.72$ \\
\hline
\end{tabular}

1/ DAE - days after emergence; $\underline{2}$ / Means followed by the same letter, uppercase in the rows and lowercase in the columns, do not differ by Tukey's test at $5 \%$ significance; $\underline{3}$ / Daily - daily irrigation with $5 \mathrm{~mm}$; Intermittent- weekly irrigation with $5 \mathrm{~mm}$ LSD least significant difference; CV - coefficient of variation.

Thus, in more acidic soils, chlorimuron remains as a molecule and has higher retention by colloids; in contrast, in more alkaline soils (Tables 1 and 2), most of the product will remain in its ionic (anionic) form with lower retention by soil colloids. In the soil samples, with $\mathrm{pH}$ at 6.4 and 6.3 , virtually all of the herbicide remained in its ionic (anionic) form, more available in the soil solution and more prone to leaching. The sandy soil ( $\mathrm{pH}$ 6.3) has only $13.2 \%$ clay and, consequently, lower anion exchange capacity. In this case, the higher availability of the molecule in the soil solution increases the phytotoxicity values in the short term; however, in the long run, the product has greater leaching rate and lower persistence.

The $\mathrm{S} x \mathrm{~T}$ interaction (Table 5 ) is consistent with the previous discussion. In sandy soil, all prior application dates allowed the perfect future development of corn plants, equal to that of the control without application. It can be seen, therefore, that the interference of soil type in herbicide leaching is a major factor in dissipation speed, thus reducing toxicity in succeeding crops.

In the clay soil, there is a greater impediment to leaching and therefore greater retention of chlorimuron. In this case, the determining factor for herbicide dissipation was probably the microbial decomposition of the molecule (Beckie \& McKercher, 1989; Rodrigues \& Almeida, 2011), since the hydrolysis rate of the molecule is minimal at pH greater than 6.0 (Sarmah \& Sabadie, 2002). In the clay soil, the 90-day interval between herbicide application and corn seeding improved plant growth (Table 5), but not at the same level as the control.

Similar results were found by Artuzi \& Contiero (2006), after application of chlorimuron $\left(15 \mathrm{~g} \mathrm{ha}^{-1}\right)$ in soybean crops in clay soil (70.5\% clay). The major symptoms in the corn crops were observed for seeding on the same day of application. These authors reported a reduction in plant size and height, severe chlorosis, necrosis at the leaf tips, and purple color at the midrib and at the bottom of plants. However, in that case, the 30-day interval between application of chlorimuron and corn seeding was enought to reduce toxicity grade from 4 to 1 , and ensure productivity was equal to that of the control without application. In conclusion, the authors recommended a 60-day interval between herbicide application and corn seeding in order to ensure maximum crop yield. Dan et al. (2012), also working in clay soil, seeded corn 97 days after application of chlorimuron $\left(15 \mathrm{~g} \mathrm{ha}^{-1}\right)$ in the area. In the first phytotoxicity

Table 5 - Dry matter weight of corn plants ${ }^{1}$ seeded in soil previously sprayed with chlorimuron-ethyl, influenced by soil type and the product's application timing, assessed at 21 days after emergence. Santa Cruz das Palmeiras - SP, 2010

\begin{tabular}{|l|c|c|c|c|}
\hline \multirow{2}{*}{ Soil type (S) } & \multicolumn{5}{|c|}{ Application timing (T) } \\
\cline { 2 - 5 } & Control & $30 \mathrm{DBS}^{2 /}$ & $60 \mathrm{DBS}$ & $90 \mathrm{DBS}$ \\
\hline Sand & $2.63 \mathrm{bA}$ & $2.24 \mathrm{bA}$ & $2.42 \mathrm{bA}$ & $2.56 \mathrm{bA}$ \\
\hline Clay & $3.99 \mathrm{aA}$ & $2.81 \mathrm{aC}$ & $3.09 \mathrm{aC}$ & $3.56 \mathrm{aB}$ \\
\hline \multicolumn{2}{|c|}{$\mathrm{LSD}_{\text {Column }}=0.302$} & $\mathrm{LSD}_{\text {Row }}=0.399$ & \multicolumn{2}{c|}{$\mathrm{CV}(\%)=12.72$} \\
\hline
\end{tabular}

${ }^{1 /}$ Means followed by the same letter, uppercase in the rows and lowercase in the columns, do not differ by Tukey's test at $5 \%$ significance;

${ }^{2 /}$ DBS - days before seeding; LSD - least significant difference; CV - coefficient of variation. 
evaluation of corn crops, they observed visual damage of only $9.0 \%$, which regressed over time, without interference in crop yield.

Therefore, there is a clear combined effect of irrigation and application timings on soil persistence of chlorimuron. Evidently, the intensity of irrigation performed before corn seeding proportionately reduces the phytotoxicity of the product (Table 6) and increases dry matter weight (Table 7). Similarly, the longer the interval between application timings and later corn seeding, the better plant growth can be (Tables 6 and 7).

The analysis of variance for applications of metsulfuron methyl was similar to that of chlorimuron (Table 8). In this case, isolated effects were identified for treatment factors

Table 6 - Phytotoxicity of corn per plants ${ }^{1 /}$ seeded in soil previously sprayed with chlorimuron-ethyl, influenced by application timing and irrigation regime, measured at 7 and 14 days after emergence (DAE). Santa Cruz das Palmeiras SP, 2010

\begin{tabular}{|l|c|c|c|}
\hline \multirow{2}{*}{ Irrigation (I) } & \multicolumn{3}{|c|}{ Application Timing (T) } \\
\cline { 2 - 4 } & $30 \mathrm{DBS}^{2 /}$ & $60 \mathrm{DBS}$ & $90 \mathrm{DBS}$ \\
\hline \multicolumn{4}{|c|}{$7 \mathrm{Days}$ after emergence } \\
\hline Daily & $3.0 \mathrm{bA}$ & $2.8 \mathrm{bAB}$ & $2.0 \mathrm{bB}$ \\
\hline Intermittent & $4.6 \mathrm{aA}$ & $2.6 \mathrm{bB}$ & $1.4 \mathrm{bC}$ \\
\hline $\mathrm{N}^{0}$ irrigation & $5.5 \mathrm{aA}$ & $5.4 \mathrm{aA}$ & $4.7 \mathrm{aA}$ \\
\hline & $\mathrm{LSD}_{\text {Column }}=0.895$ & $\mathrm{LSD}_{\text {Row }}=0.895$ & $\mathrm{CV}(\%)=21.63$ \\
\hline \multicolumn{5}{|c|}{14 Days after emergence } \\
\hline Daily & $2.4 \mathrm{cA}$ & $2.2 \mathrm{bA}$ & $1.6 \mathrm{bA}$ \\
\hline Intermittent & $3.4 \mathrm{bA}$ & $1.6 \mathrm{bB}$ & $1.2 \mathrm{bB}$ \\
\hline No irrigation & $5.2 \mathrm{aA}$ & $5.2 \mathrm{aA}$ & $4.0 \mathrm{aB}$ \\
\hline & $\mathrm{LSD}_{\text {Column }}=0.983$ & $\mathrm{LSD}_{\mathrm{Row}}=0.983$ & $\mathrm{CV}(\%)=28.32$ \\
\hline
\end{tabular}

${ }^{1 /}$ Means followed by the same letter, uppercase in the rows and lowercase in the columns, do not differ by Tukey's test at 5\% significance; 르 DBS - days before sowing; LSD - least significant difference; CV - coefficient of variation. and for the double I $\mathrm{x} T$ interaction for all variables; the S x I interaction was significant for dry matter weight, while the triple interaction $\mathrm{S} \times \mathrm{I} \times \mathrm{T}$ was significant only for phytotoxicity at $7 \mathrm{DAE}$ (Table 8).

In general, there were not many meaningful interactions for metsulfuron with the soil factor, which is indicative of a smaller influence of soil on herbicide behavior. This observation is in agreement with KotoulaSyka et al. (1993). These authors evaluated phytotoxicity and persistence of metsulfuron in three agricultural soils and found that the damage caused to crops were not related to soil type, but rather with product rate and soil $\mathrm{pH}$. Increasing product rate increased persistence in the environment, as well as leaching rate.

Metsulfuron-methyl is also a weak acid with $\mathrm{pKa}$ of 3.3. It has $\mathrm{K}_{\text {ow }}$ of 1.0 at $\mathrm{pH} 5.0$ and $\mathrm{K}_{\text {ow }}$ of 0.018 at $\mathrm{pH} 7$, suggesting little sorption to soil colloids. Moreover, its solubility is $270 \mathrm{mg} \mathrm{L}^{-1}$ at $\mathrm{pH} 5.0$ and 9,500 $\mathrm{mg} \mathrm{L}^{-1}$ at $\mathrm{pH} 7.0$, i.e., metsulfuron-methyl is much more soluble than chlorimuron. Its major degradation pathways are microbial and hydrolytic; the latter is not very significant at pH above 6.0 (Krevalis et al., 2006; Roberts \& Almeida, 2011). Thus, the behavior of metsulfuron in soils is similar to that of chlorimuron, but the former is more likely to remain bioavailable in the soil solution, because it has high solubility and low $\mathrm{K}_{\mathrm{ow}}$, which can also facilitate leaching in the profile.

Greater dry matter weight was found for the clay soil, possibly due to its physicochemical properties (Table 9). Also in

Table 7 - Dry matter weight of corn plants ${ }^{1}$ s seeded in soil previously sprayed with chlorimuron-ethyl, influenced by application timing and irrigation regime, evaluated at 21 days after emergence (DAE). Santa Cruz das Palmeiras - SP, 2010

\begin{tabular}{|l|l|l|l|c|}
\hline \multirow{2}{*}{ Irrigation (I) } & \multicolumn{4}{|c|}{ Application Timing (T) } \\
\cline { 2 - 5 } & Control & $30 \mathrm{DBS}^{2} /$ & $60 \mathrm{DBS}$ & $90 \mathrm{DBS}$ \\
\hline Daily & $3.55 \mathrm{aA}$ & $2.97 \mathrm{aB}$ & $3.25 \mathrm{aAB}$ & $3.66 \mathrm{aA}$ \\
\hline Intermittent & $3.31 \mathrm{abA}$ & $2.54 \mathrm{aB}$ & $2.91 \mathrm{aAB}$ & $3.28 \mathrm{aA}$ \\
\hline No irrigation & $3.07 \mathrm{bA}$ & $2.07 \mathrm{bB}$ & $2.11 \mathrm{bB}$ & $2.26 \mathrm{bB}$ \\
\hline \multicolumn{2}{|c|}{ LSD $_{\text {Column }}=0.444$} & LSD $_{\text {Row }}=0.488$ & \multicolumn{2}{c|}{$\mathrm{CV}(\%)=12.72$} \\
\hline
\end{tabular}

${ }^{1 /}$ Means followed by the same letter, uppercase in the rows and lowercase in the columns, do not differ by Tukey's test at $5 \%$ significance;

${ }^{2 /}$ DBS - days before seeding; LSD - least significant difference; CV - coefficient of variation. 
Table 8 - Table of variance analysis and comparison of means ${ }^{1 /}$ for phytotoxicity (7 and 14 days after emergence (DAE)) and dry matter weight (21 DAE) of corn plants seeded in soil previously sprayed with metsulfuron-methyl. Santa Cruz das Palmeiras - SP, 2010

\begin{tabular}{|c|c|c|c|}
\hline Cause of variation & Phytotoxicity at 7 DAE & Phytotoxicity at $14 \mathrm{DAE}$ & Dry matter \\
\hline Soil (S) & $* *$ & $* *$ & $* *$ \\
\hline Irrigation (I) & $* *$ & $* *$ & $* *$ \\
\hline Application Timing (T) & $* *$ & $* *$ & $* *$ \\
\hline $\mathrm{S} \times \mathrm{I}$ & ns & ns & $* *$ \\
\hline $\mathrm{S} \times \mathrm{T}$ & ns & ns & ns \\
\hline $\mathrm{Ix} \mathrm{T}$ & $* *$ & $* *$ & $*$ \\
\hline $\mathrm{S} \times \mathrm{I} \times \mathrm{T}$ & $* *$ & ns & ns \\
\hline \multicolumn{4}{|c|}{ Soil type (S) } \\
\hline Clay & $1.8 \mathrm{~b}$ & $1.4 \mathrm{~b}$ & $3.79 \mathrm{a}$ \\
\hline Sandy & $2.7 \mathrm{a}$ & $1.9 \mathrm{a}$ & $2.51 \mathrm{~b}$ \\
\hline \multicolumn{4}{|c|}{ Irrigation (I) } \\
\hline Daily & $1.7 \mathrm{~b}$ & $1.3 \mathrm{~b}$ & $3.44 \mathrm{a}$ \\
\hline Intermittent & $1.9 \mathrm{~b}$ & $1.5 \mathrm{~b}$ & $3.22 \mathrm{a}$ \\
\hline No irrigation & $3.0 \mathrm{a}$ & $2.2 \mathrm{a}$ & $2.79 \mathrm{~b}$ \\
\hline \multicolumn{4}{|c|}{ Application Timing (T) } \\
\hline Control & --- & --- & $3.21 \mathrm{a}$ \\
\hline $30 \mathrm{DBS}^{2 /}$ & $3.0 \mathrm{a}$ & $2.1 \mathrm{a}$ & $2.88 \mathrm{~b}$ \\
\hline 60 DBS & $2.1 \mathrm{~b}$ & $1.7 \mathrm{a}$ & $3.17 \mathrm{ab}$ \\
\hline $90 \mathrm{DBS}$ & $1.6 \mathrm{~b}$ & $1.1 \mathrm{~b}$ & $3.33 \mathrm{a}$ \\
\hline
\end{tabular}

${ }^{1 /}$ Means followed by the same letter in the columns do not differ by Tukey test at $5 \%$ significance; ${ }^{2 /}$ DBS - days before sowing; * F-test significant at $5 \%$ probability; ${ }^{* *}$ F-test significant at $1 \%$ probability; ${ }^{\text {ns }}$ Non-significant.

the case of metsulfuron, the shorter intervals between product application and corn seeding increased the phytotoxicity of plants. However, it was decreased in plots that received weekly or daily irrigation (Table 10). In general, there was less toxicity of corn plants with metsulfuron, with maximum values of 4.3 (Table 10). There was higher damage for chlorimuron-ethyl, up to 5.5 (Table 6).

Table 9 - Dry matter weight of dry corn plants ${ }^{1 /}$ seeded in soil previously sprayed with metsulfuron-methyl, influenced by soil type and irrigation regime, evaluated at 21 days after emergence (DAE). Santa Cruz das Palmeiras - SP, 2010

\begin{tabular}{|l|c|c|c|}
\hline \multirow{2}{*}{$\begin{array}{c}\text { Soil type } \\
(\mathrm{S})\end{array}$} & \multicolumn{3}{|c|}{ Irrigation regime (I) } \\
\cline { 2 - 4 } & Daily $^{2 /}$ & Intermittent & No irrigation \\
\hline Sandy & $2.52 \mathrm{bAB}$ & $2.67 \mathrm{bA}$ & $2.34 \mathrm{bB}$ \\
\hline Clay & $4.36 \mathrm{aA}$ & $3.77 \mathrm{aB}$ & $3.24 \mathrm{aC}$ \\
\hline & $\mathrm{LSD}_{\text {Column }}=0.269$ & $\mathrm{LSD}_{\text {Row }}=0.324$ & $\mathrm{CV}(\%)=12.14$ \\
\hline
\end{tabular}

${ }^{1 /}$ Means followed by the same letter, uppercase in the rows and lowercase in columns, do not differ by Tukey's test at 5\% significance; 늘 Daily - daily irrigation with $5 \mathrm{~mm}$; Intermittent weekly irrigation with $5 \mathrm{~mm}$; LSD - least significant difference; CV - coefficient of variation.
Ivany (1987), while evaluating the residual effect of metsulfuron on crops seeded in

Table 10 - Phytotoxicity of corn plants $\stackrel{1}{1}$ seeded in soil previously sprayed with metsulfuron-methyl, influenced by irrigation regime and herbicide application timing, measured at 7 and 14 days after emergence (DAE). Santa Cruz das Palmeiras - SP, 2010

\begin{tabular}{|l|c|c|c|}
\hline \multirow{2}{*}{ Irrigation (I) } & \multicolumn{3}{|c|}{ Application timing (T) } \\
\cline { 2 - 4 } & $30 \mathrm{DBS}^{2 /}$ & $60 \mathrm{DBS}$ & $90 \mathrm{DBS}$ \\
\hline \multicolumn{4}{|c|}{7 Days after emergence } \\
\hline Daily & $1.8 \mathrm{cA}$ & $1.6 \mathrm{bA}$ & $1.6 \mathrm{aA}$ \\
\hline Intermittent & $2.9 \mathrm{bA}$ & $1.8 \mathrm{bB}$ & $1.3 \mathrm{aB}$ \\
\hline $\mathrm{N}^{\circ}$ irrigation & $4.3 \mathrm{aA}$ & $2.9 \mathrm{aB}$ & $2.0 \mathrm{aC}$ \\
\hline & $\mathrm{LSD}_{\text {Column }}=0.864$ & $\mathrm{LSD}_{\text {Row }}=0.864$ & $\mathrm{CV}(\%)=33.21$ \\
\hline \multicolumn{5}{|c|}{14 Days after emergence } \\
\hline Daily & $1.3 \mathrm{bA}$ & $1.6 \mathrm{abA}$ & $1.1 \mathrm{aA}$ \\
\hline Intermittent & $1.9 \mathrm{bA}$ & $1.4 \mathrm{bAB}$ & $1.1 \mathrm{aB}$ \\
\hline No irrigation & $3.3 \mathrm{aA}$ & $2.1 \mathrm{abA}$ & $1.1 \mathrm{aC}$ \\
\hline & $\mathrm{LSD}_{\text {Column }}=0.725$ & $\mathrm{LSD}_{\text {Row }}=0.725$ & $\mathrm{CV}(\%)=37.18$ \\
\hline
\end{tabular}

${ }^{1 /}$ Means followed by the same letter, uppercase in the rows and lowercase in the columns, do not differ by Tukey's test at $5 \%$ significance; 2` DBS - days before sowing; LSD - least significant difference; CV - coefficient of variation. 
Table 11 - Dry matter weight of corn plants ${ }^{1 /}$ seeded in soil previously sprayed with metsulfuron-methyl, influenced by application timing and irrigation regime, evaluated at 21 days after emergence (DAE). Santa Cruz das Palmeiras - SP, 2010

\begin{tabular}{|l|c|c|c|c|}
\hline \multirow{2}{*}{ Irrigation (I) } & \multicolumn{5}{|c|}{ Application timing (T) } \\
\cline { 2 - 5 } & Control & $30 \mathrm{DBS}^{2 /}$ & $60 \mathrm{DBS}$ & $90 \mathrm{DBS}$ \\
\hline Daily & $3.30 \mathrm{aA}$ & $3.51 \mathrm{aA}$ & $3.39 \mathrm{aA}$ & $3.56 \mathrm{aA}$ \\
\hline Intermittent & $3.39 \mathrm{aA}$ & $2.85 \mathrm{bB}$ & $3.34 \mathrm{aAB}$ & $3.30 \mathrm{aAB}$ \\
\hline No irrigation & $2.93 \mathrm{aA}$ & $2.30 \mathrm{cB}$ & $2.80 \mathrm{bAB}$ & $3.14 \mathrm{aA}$ \\
\hline \multicolumn{2}{|c|}{} & LSD $_{\text {Row }}=0.503$ & \multicolumn{2}{c|}{$\mathrm{CV}(\%)=12.14$} \\
\hline
\end{tabular}

$1 /$ Means followed by the same letter, uppercase in the rows and lowercase in the columns, do not differ by Tukey's test at 5\% significance;

2/ DBS - days before sowing; LSD - least significant difference; CV - coefficient of variation.

succession, found damage to corn plants even after 120 days of soil persistence. However, in that research study, all the irrigation conditions allowed the perfect development of corn plants when metsulfuron was applied at 90 DBS (Table 11). The short interval between herbicide application and corn sowing hindered plant development. At 30 DBS, only daily irrigation ensured equal weight when the experimental control is compared with corn seeded into the treated soil (Table 11).

In short, the dissipation of these sulfonylurea herbicides in agricultural soils was directly influenced by water availability, by molecule solubility (leaching potential) and the time available for microbial degradation in soil. In the sandy soil with adequate water supply, leaching was more important, as it favored short intervals between herbicide application and corn seeding. In clay soil, microbial degradation is significant, so that the higher the time available for microbial activity, the lesser damage to corn, provided that the environment has adequate water availability. The herbicide metsulfuronmethyl was less phytotoxic to corn plants, possibly due to the characteristics of its molecule and its greatest potential for leaching.

\section{LITERATURE CITED}

ARTUZI, J. P.; CONTIERO, R. L. Herbicidas aplicados na soja e produtividade do milho em sucessão. Pesq. Agropec. Bras., v. 41, n. 7, p. 1119-1123, 2006.

BECKIE, H. J.; McKERCHER, R. B. Soil residual properties of DPX-A7881 under laboratory conditions. Weed Sci., v. 37, n. 3, p. 412-418, 1989.
CARVALHO, F. T.; CAVAZZANA, M. A. Eficácia de herbicidas no manejo de plantas daninhas para o plantio direto da soja. R. Bras. de Herbic., v. 1, n. 2, p. 167-172, 2000.

CHRISTOFFOLETI, P. J. et al. Comportamento dos herbicidas aplicados ao solo na cultura da cana-deaçúcar. Piracicaba: CP 2, 2009. 72 p.

DAN, H. A. et al. Resíduos de herbicidas utilizados na cultura da soja sobre o milho cultivado em sucessão. R. Caatinga, v. 25, n. 1, p. 86-91, 2012.

EUROPEAN WEED RESEARCH COUNCIL - EWRC. Report of $3^{\text {rd }}$ and $4^{\text {th }}$ meetings of EWRC. Committee of methods in weed research. Weed Res., v. 4, n. 1, p. 88, 1964.

HEAP, I. International survey of herbicide resistant weeds: herbicide resistant weeds in Brazil. Disponível em: $<$ http://www.weedscience.com/Summary/Country.aspx>. Acesso em: 9 out. 2014.

IVANY, J. A. Metsulfuron use in barley and residual effect on succeeding crops. Canadian J. Plant Sci., v. 67, n. 4, p. 1083-1088, 1987.

KATOULA-SYKA, E. et al. Phytotoxicity and persistence of chlorsulfuron, metsulfuron-methyl, triasulfuron and tribenuronmethyl in three soils. Weed Res., v. 33, n. 5, p. 355-367, 1993.

KREVALIS, M. A. et al. Investigation into the use of hydroxycontaining amides for oil flowable formulations. In.: SALYANI, M.; LINDNER, G. (Ed.). Pesticide formulations and delivery systems, $\mathbf{2 5}^{\text {th }}$ volume: advances in crop protection technologies. West Conshohocken: ASTM, 2006. p. 51-61.

MILANOVA, S.; GRIGOROV, P. Movement and persistence of imazaquin, oxyfluorfen, flurochloridone and terbacil in soil. Weed Res., v. 36, n. 1, p. 31-36, 1996.

MOREIRA, M. S. et al. Herbicidas alternativos para controle de biótipos de Conyza bonariensis e C. canadensis resistente ao glyphosa. Planta Daninha, v. 28, n. 1, p. 167-175, 2010. 
OGG JÚNIOR, A. G.; DOWLER, C. C. Applying herbicides through irrigation systems. In: McWORTHER, C. G.; GEBHARDT, M. R. (Ed.). Methods of applying herbicides. Champaign: WSSA, 1988. p. 145-164.

OLIVEIRA JÚNIOR, R. S. et al. Influência do período de restrição hídrica na atividade residual de isoxaflutole no solo. Planta Daninha, v. 24, n. 4, p. 733-740, 2006.

PAULA, J. M. et al. Manejo de Conyza bonariensis resistente ao herbicida glyphosate. Planta Daninha, v. 29, n. 1, p. 217-227, 2011.

PETERSON, D. E. The impact of herbicide-resistant weeds on Kansas agriculture. Weed Technol., v. 13, n. 3, p. 632-635, 1999.
RODRIGUES, B. N.; ALMEIDA, F. S. Guia de herbicidas. 5.ed. Londrina: Autores, 2011. 697 p.

SANTOS, F. M. et al. Differential susceptibility of biotypes of Conyza sumatrensis to chlorimuron-ethyl herbicide.

Planta Daninha, v. 32, n. 2, p. 427-435, 2014.

SARMAH, A. K.; SABADIE, J. Hydrolysis of sulfonylurea herbicides in soils and aqueous solutions: a review. J. Agric. Food Chem., v. 50, n. 22, p. 6253-6265, 2002.

VALENTE, T. O.; CAVAZZANA, M. A. Efeito residual de chlorimuron-ethyl aplicado em mistura com glyphosate na dessecação de plantas daninhas. R. Bras. Herbic., v. 1, n. 2, p. 173-178, 2000. 